(С) І.Д. Малицька, 2011

ISSN 2076-8184. Інформаційні технології і засоби навчання. 2011. №3 (23).

Режим доступу до журналу: http://www.journal.iitta.gov.ua

Малицька Ірина Дмитрівна, старший науковий співробітник нформаційноаналітичного відділу педагогічних інновацій Інституту інформаційних технологій і засобів навчання НАПН України, м. Київ, е-mail: Irina_Malitskaya@mail.ru

\title{
ГЛОБАЛЬНІ ОСВІТНІ МЕРЕЖІ ТА ЇХ КОМУНІКАТИВНИЙ ПОТЕНЦІАЛ (ЗАРУБІжНИЙ ДОСВІД)
}

\section{Анотація}

В статті проаналізовано основні тенденції розвитку глобальних освітніх мереж, таких як GINIE, GLORIAD, Global Knowledge Partnership (GKP), Xplora, визначено основні сучасні тенденції їх розвитку, які спрямовані на створення віртуальних освітніх спільнот 3 подальшим формуванням єдиного освітнього простору. Розглянуто такі мережі як: Globalschoolnet, Educared, HappyChild, Teachers Network, на основі яких створюються і успішно діють освітні віртуальні спільноти. Визначено основні форми навчальних ресурсів освітніх мереж, які використовуються у навчально-виховному процесі загальної середньої школи зарубіжних країн.

Ключові слова: інформаційно-комунікаційні технології, глобальні освітні мережі, віртуальні освітні спільноти, єдиний освітній простір

Одним із критеріїв визначення рівня розвитку сучасних суспільств є рівень розвитку процесів інформатизації, впровадження інформаційно-комунікаційних технологій (ІКТ), ІКТ грамотність населення, його підготовленість до використання цифрових технологій у різних сферах життя, що стає вимогою часу. Підготовка майбутніх громадян суспільства, якими $\epsilon$ учні загальноосвітніх навчальних закладів, повинна відповідати викликам сучасності, ураховувати вимоги сучасного ринку праці. Визнаючи важливість і швидке розповсюдження інформаційно-комунікаційних технологій в системах освіти зарубіжних країн одними із пріоритетних напрямів свого розвитку визначено впровадження i освоєння IКТ на всіх рівнях навчання.

Нагальна потреба постійної модернизації IКТ в освіті, їх інтегрування у процес викладання різних предметів у школі спонукає до вивчення проблем, які 
виникають в процесі використання IКT, розвитку та втіленню у навчальний процес інноваційних підходів та знаходження відповідних рішень. Над цією тематикою постійно працюють освітяни $з$ різних країн світу: Девід Боуден (США), Сердж Віркус (Великобританія), Полат Є.С., Хуторской А.В. (Росія), Биков В.Ю., Морзе Н.В., Раков С.А. (Україна) та багато інших.

Метою статmі $\epsilon$ проаналізувати основні тенденції розвитку глобальних освітніх мереж, які сприяють створенню єдиного інформаційного освітнього простору, для подальшого їх урахування у визначенні напрямів розвитку системи освіти України, які б відповідали світовим тенденціям.

Важливість розвитку, впровадження і використання інформаційнокомунікаційних технологій (IКТ) підтверджується різними нормативними i установчими документами, прийнятими країнами-членами Свропейського Союзу, Ради Свропи і України зокрема, такими як: Стратегї «СС 2020», Лісабонська стратегія, Окінавська Хартія глобального інформаційного суспільства, Державна програма України «Інформаційні та комунікаційні технології в освіті і науці», Закон України «Про Національну програму інформатизації» та інші, однією 3 основних цілей яких $\epsilon$ формування інформаційного суспільства, розвиваючи i використовуючи інноваційні інформаційні технології на всіх рівнях навчання.

Продовжуючи процес інформатизації української системи освіти у серпні 2010 року Розпорядженням Кабінету Міністрів України № 1722-р було схвалено Концепцію Державної цільової програми впровадження у навчально-виховний процес загальноосвітніх закладів інформаційно-комунікаційних технологій "Сто відсотків" на період до 2015 року [1], в якій визначені шляхи реалізації цієї програми одними з яких є:

- «надання всім загальноосвітнім навчальним закладам швидкісного доступу до Інтернету 3 використанням сучасних технологій під’єднання для високоефективного доступу до освітніх ресурсів;

- створення системи веб-сайтів всіх загальноосвітніх навчальних закладів для опублікування кращих освітянських надбань, підтримки колективної та індивідуальної комунікації, формування мережних професійних об’єднань;

- $\quad$ створення єдиного освітнього середовища та інформаційної інтеграції освітніх ресурсів». 
Таким чином, можна зазначити, що напрями розвитку системи освіти України і впровадження ІКТ у навчальний процес різних рівней освіти співпадають 3 основними пріоритетами розвитку систем освіти інших європейських країн. Глобальні освітні мережі, які самі по собі є ІКТ, відіграють важливу роль у цих процесах і сприяють створенню єдиного освітнього простору.

Одними з найбільш відомих глобальних освітніх мереж залишаються такі як:

- GINIE (Global Information Networks in Education) - Глобальні інформаційні мережі в освіті [2]. Заснована у 1995 році за підтримки Американського центру 3 гуманітарного розвитку (HDC), Американського агентства для міжнародного розвитку (USAID), з метою підтримки та проведення довгострокових програм, пов’язаних $з$ дослідженнями та технічною підтримкою освіти для гуманітарного розвитку націй у період конфліктних ситуацій. Проекти мережі спрямовані на створення віртуальних навчаючих середовищ, які об’єднують освітян різних країн світу, сприяють їх спільній співпраці з метою визначення основних пріоритетів і напрямів розвитку сучасних систем освіти.

- Global Knowledge Partnership (GKP) [3] - Глобальне партнерство в ім'я знання - одна з лідерів глобальних інформаційних мереж створена у 1997 році 3 метою використання інформаційних та комунікаційних технологій у різних сферах життя, включаючи освіту.

- GLORIAD (Global Ring Network for Advanced Applications Development) [4] Глобальна кільцева комп’ютерна мережа, заснована Росією, США та Китаєм у 2004 році з метою підтримки та розвитку науки та освіти, зміцненню та покращенню співробітництва між країнами світу. До неї входять Корея, Канада та Нідерлінди, до роботи мережі залучені учні, студенти, вчителі, дослідники з Свропи, Азії та Америки, створюючи таким чином навчальні та досліднищькі віртуальні спільноти. Основна робота спрямована на спільну співпрацю науковців, освітян, студентів та школярів старших класів та виклики сучасного життя в глобальному вимірі. Базуючись на використанні сучасних телекомунікаційних технологіях (зокрема IP-телефонії) мережа дає можливість та вчить іiі користувачів спілкуватися і проводити дискусії у реальному часі через відео-сесії, відео та аудіоконференції. 
Визнаючи важливість розвитку в учнів креативного мислення, вміння знаходити та вилучати необхідну інформацію 3 метою проведення самостійних наукових дослідженнь в процесі навчання, особливе місце в системах освіти зарубіжних країн займає створення науково-інформаційного простору, насамперед для дітей та молоді 3 використанням для цього нових комунікаційноінформаційних засобів.

Таким прикладом може слугувати глобальна освітня мережа Xplora (Рис.1), яку називають Європейськими воротами до освіти, спрямованої на формування дослідницьких вмінь та навичок [5].

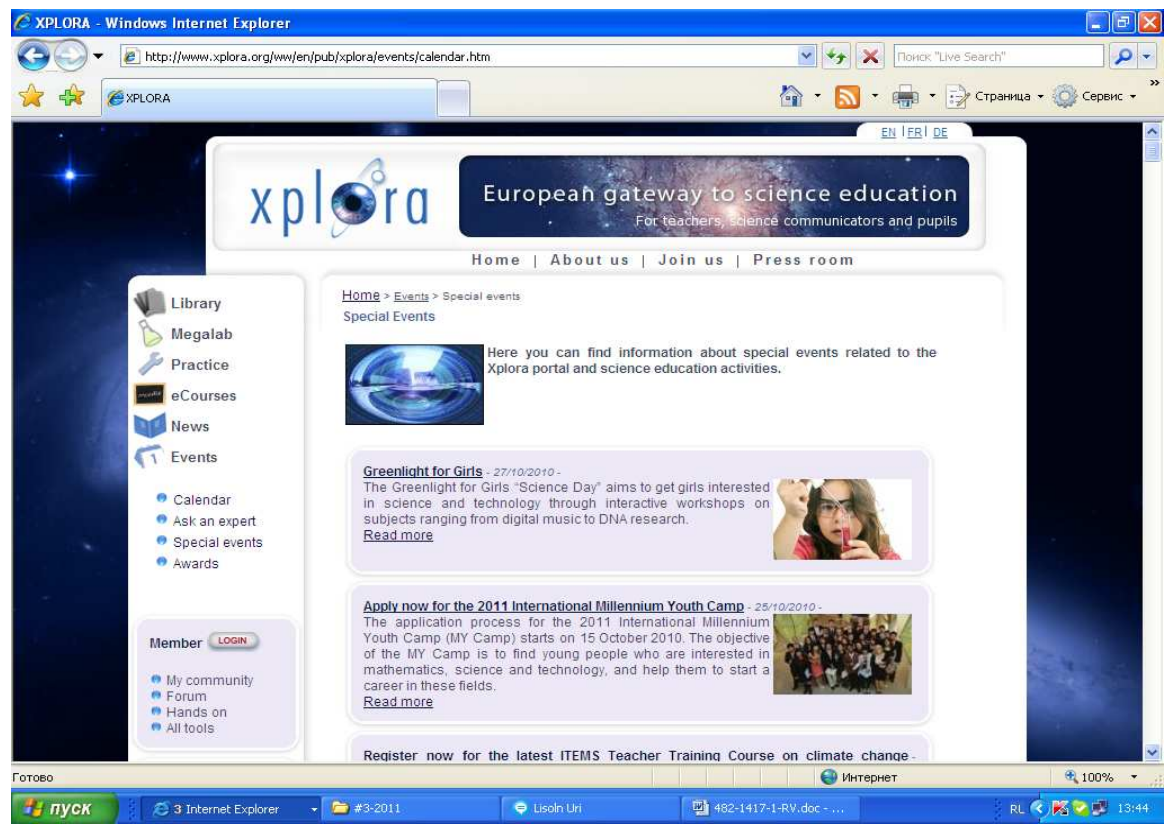

Рис.1. Головна сторінка мережі Xplora

Вказана мережа об’єднує учнів, вчителів та науковців, надає можливість ознайомитись 3 новинами, педагогічними винаходами, інноваційними ідеями; проводити пошук по базам даних та різним електронним джерелам; приймати участь в семінарах та конференціях в режимі он-лайн; ознайомитись 3 інноваційними напрямами та проектами в освіті i науці; використовувати різноманітні інформаційно-комунікаційні технології, які розміщені на мережі безкоштовно.

До основної наукової групи мережі увійшли вчителі, які мають свій власний інноваційний педагогічний підхід, високий рівень компетентності у використанні інструментів IKT та здатні ефективно співпрацювати 3 міжнародним співтовариством. Проекти, ініційовані мережею, мають на меті охопити всі рівні навчання починаючи з початкового та об'єднати у своїй роботі не тільки школи, 
але й державні і недержавні установи, створюючи таким чином віртуальні науководослідницькі спільноти.

Заслуговує на увагу глобальна освітня мережа Global Development learning Network [6] (Глобальна мережа з розвитку навчання), яка працює на двох мовах англійській та іспанській, охоплюючи всі континенти світу. Створена за підтримки Світового банку мережа спрямована на об’єднання організацій, які займаються дистанційним навчанням, втіленням та розвитком ІКТ технологій у навчальні процеси, а також різними проблемами з розвитку систем освіти та їх пріоритетних напрямів, сприяючи, таким чином, створенню єдиного освітнього простору у глобальному вимірі. Основними інструментами є проведення відеотелекомунікаційних конференцій, семінарів, форумів, лекцій, які об’єднують фахівців різних континентів.

Аналіз процесів створення та розвитку глобальних освітніх мереж показав, що якщо на початку свого існування ( 70 - 80 роки XX-го століття) освітні мережі (ENIRDEM - Свропейська мережа для покращення досліджень та розвитку в управлінні освітою; IEA - Міжнародна асоціація з оцінювання досягнень в освіті; IBE - Міжнародне бюро з освіти; INISTE - Міжнародна мережа з науково освітньої інформації; мережі Європейського Союзу та Ради Європи як EURYDICE (Інформаційна мережа 3 питань освіти Європейського Союзу), EUDISED (Свропейські документаційні та інформаційні системи для освіти), CEDEFOP (Свропейський центр 3 розвитку професійної підготовки), ENIC Network (Свропейська мережа національних інформаційних центрів), та інші.; глобальні освітні мережі (GINIE (Global Information Networks in Education) - Глобальні інформаційні мережі в освіті, GSN (Global SchoolNet Foundation) - Фундація глобальної шкільної мережі, Global Knowledge Partnership (GKP), GLORIAD та інші) були спрямовані більш на накопичення, аналіз, розповсюдження інформації, обмін досвідом між освітянами різних країн, проведенням спільних проектів, на цей час, використовуючи новітні можливості і технології мережі Інтернет (сервіси Веб 2.0, блоги, подкастери та інші) більш спрямовують свою діяльність на створення віртуальних освітніх спільнот i поступове формування єдиного інформаційного освітнього простору у глобальному вимірі. 
Аналізуючи вже існуючи віртуальні освітні спільноти або он-лайн спільноти, можна зазначити, що вони створюються за різними ознаками і мають як постійний, так і тимчасовий стан свого існування. Так, наприклад, глобальні освітні мережі можуть слугувати як базою для їх створення (GINIE, GLORIAD, Global Knowledge Partnership (GKP) та інші) або самі по собі перетворитися на одну 3 таких спільнот (Xplora), розширюючи можливості своїх ресурсів і діяльності завдяки використанню оновлених інноваційних IКТ.

Проведений порівняльний аналіз показав, що у навчальному процесі загальної середньої освіти зарубіжних країн все частіше використовуються ресурси глобальних освітніх мереж, які спрямовані на розвиток в учнів загальнонавчальних та спеціальних навичок, навичок креативного мислення, роботі в команді, створення власних проектів, навчання 3 використання інформаційнокомунікаційних технологій не тільки у навчальному процесі, а й в особистому житті, а також допомогу вчителям з вдосконалення або навчання 3 використання ІКТ у своїй предметній галузі та у навчально-виховному процесі.

Форми і методи використання ресурсів глобальних освітніх мереж постійно удосконалюються. Електронна пошта, відео-конференції, новини, чати на цей час доповнилися популярними сучасними сервісами Веб-2.0.

Дуже важливими стають загальні принципи відкритості, конструктивної діяльності і особистої відповідальності, виникає можливість створювати свій особистий навчальний простір, свою особисту систему навчання або віртуальні спільноти об'єднані спільною ідеєю. Апробовані технології, в тому числі і сервіси Веб - 2.0, які підтримують та розвивають комунікативні навички, заохочують учнів не тільки вчитися, але й висловлювати свою думку, ідеї, відчуття, допомагають їм розвивати критичне та творче мислення.

Можна зазначити, що на цей час практично всі відомі освітні мережі (Globalschoolnet, Educared, HappyChild, Teachers Network та інші) використовують сервіси Веб-2.0, які задіяні для вивчення та навчання різних предметів, створення віртуальних спільнот тощо. Тенденцію подальшого розвитку освітніх мереж спрямовану на створення віртуальних освітніх спільнот можна прослідкувати розглядаючи сучасну діяльність таких відомих мереж як:

- GlobalSchoolNet (Рис.2) 


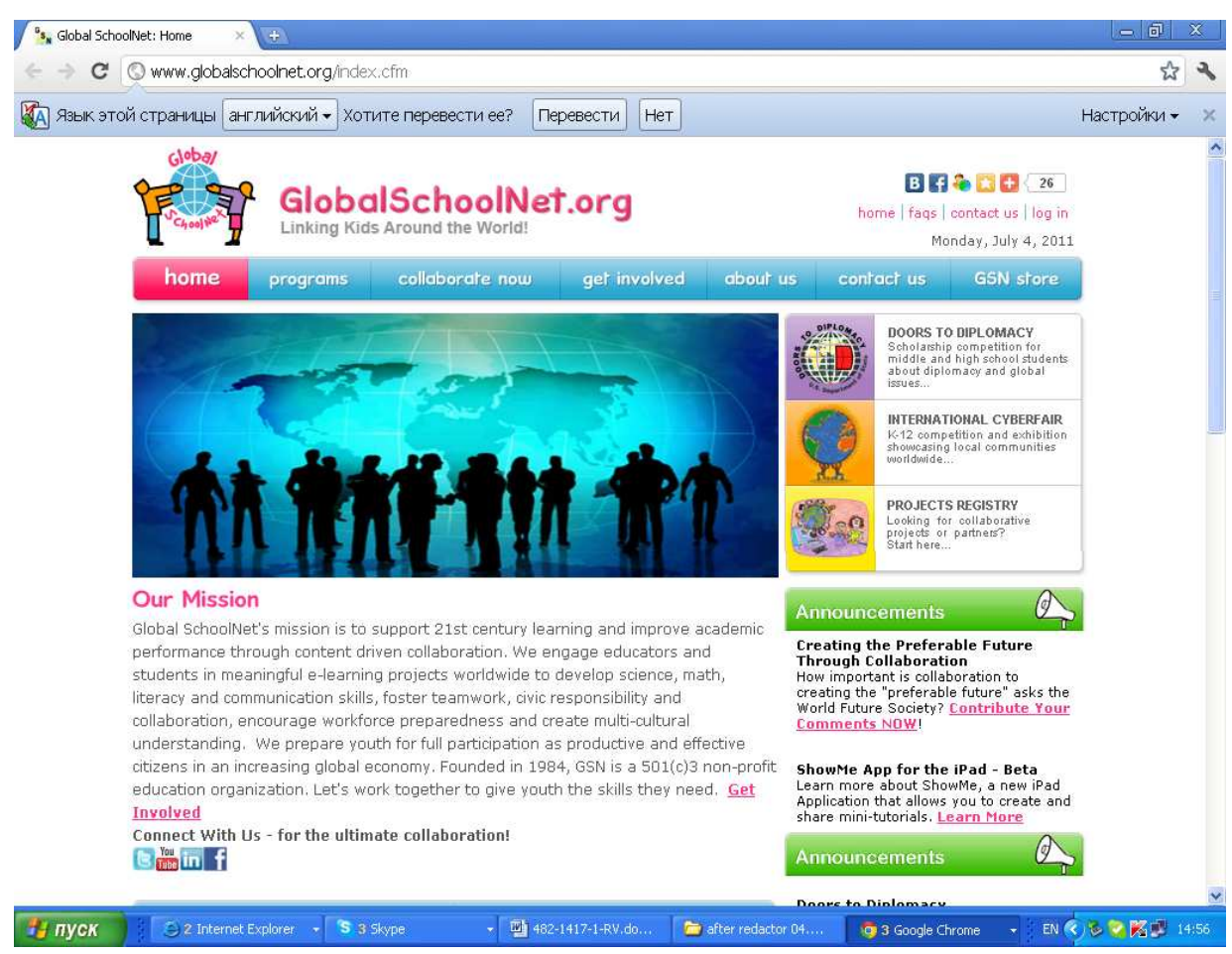

Рис.2. Головна сторінка мережі GlobalSchoolNet

На сторінках мережі розміщені сервіси, які спрямовані на розвиток комунікативних навичок та креативного мислення як для учнів, так і для вчителів, використовуючи новітне програмне забезпечення, інноваційні комп'ютерні програми та підходи, завдяки проведенню віртуальних проектів створюються віртуальні навчаючи середовища, які надають більш тісне спілкування та обмін думками між учнями, вчителями, школами, організаціями тощо [7].

- І Іспаномовна глобальна освітня мережа Educared (Рис.3)

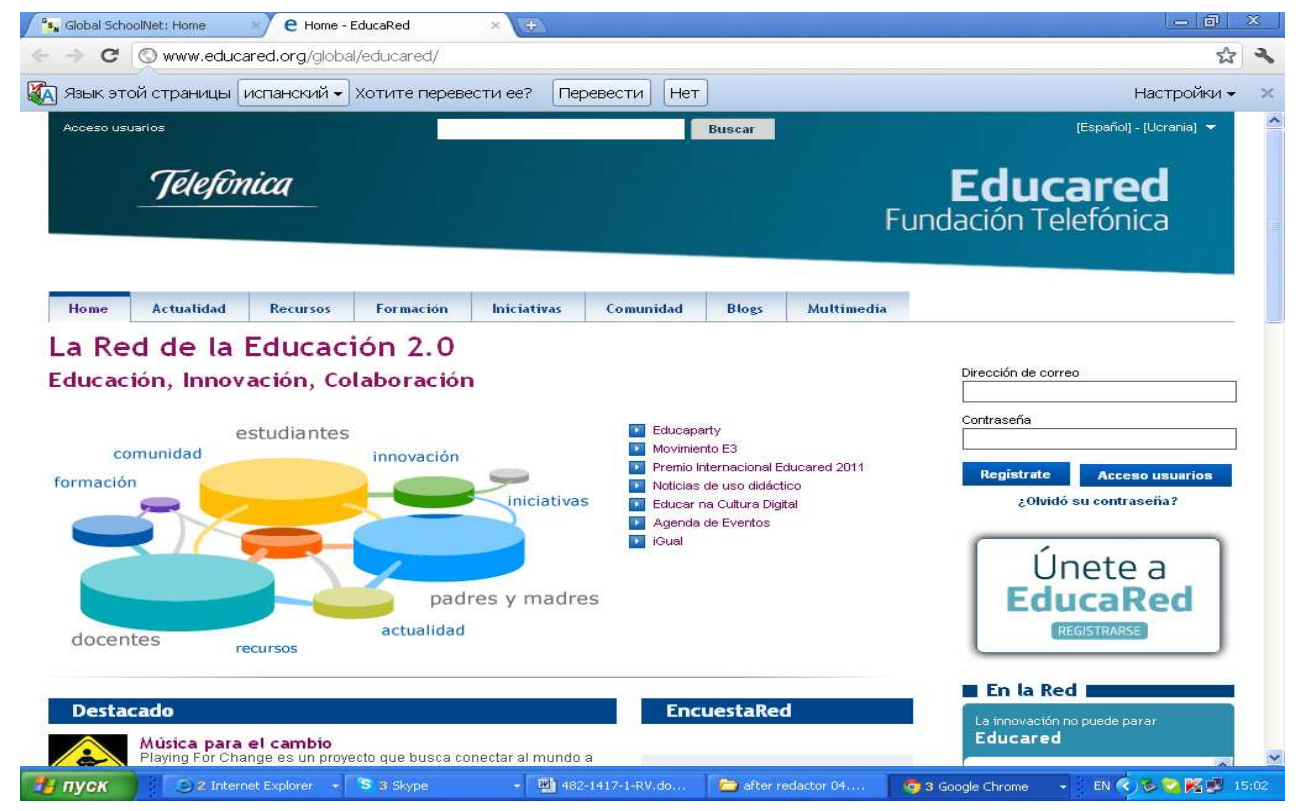

Рис.3. Головна сторінка мережі Educared 
Мережа представляє ресурси для дітей, починаючи 3 дошкільного віку, включаючи учнів, педагогів, батьків та науковців, охоплюючи школярів різних вікових категорій загальної середньої школи, створюючи таким чином віртуальні осередки, віртуальні освітні спільноти вчителів, учнів та батьків. Надаються можливості вивчення іспанської мови, географії, історії, літератури, природничих наук, освоєння комп’ютерних програм та інше. Використовуючи новітні інформаційні технології, створені розвиваючи та навчальні програми-ігри [8].

Основні напрями роботи мережі:

- сприяння навчанню та інтегруванню IКТ у навчальні процеси для викладання різних предметів;

- розміщення методичних рекомендацій;

- консультації для вчителів, учнів та їх батьків;

- сприяння інноваційним процесам та розповсюдженню педагогічних інновацій у навчальному процесі;

- он-лайн навчання з опанування IКТ.

- $\quad$ Глобальна освітня мережа НарруChild (Рис.4)

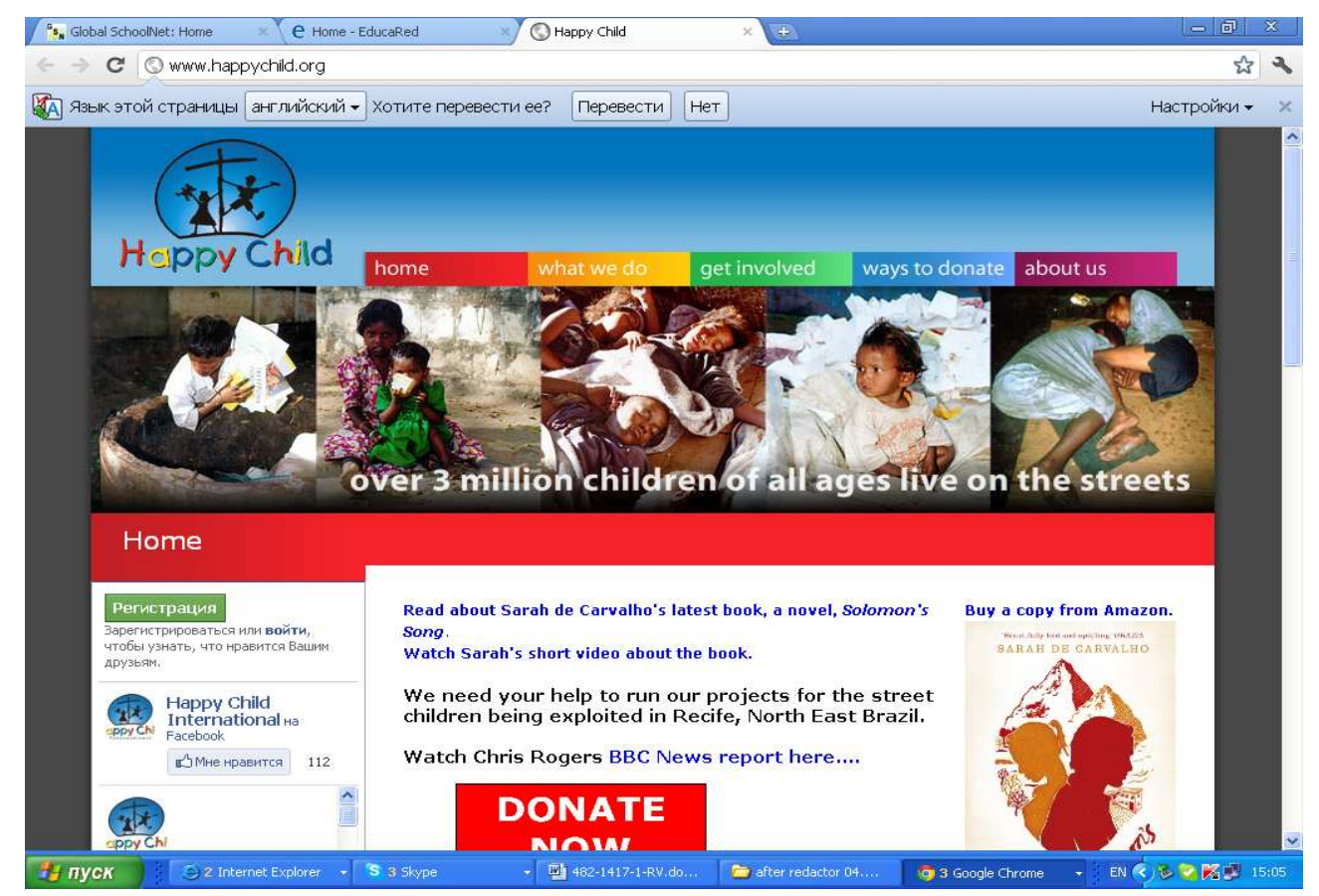

Рис.4. Головна сторінка мережі НарруChild

На сторінках мережі розміщені навчальні он-лайн ресурси для дітей початкової та середньої школи, особливу увагу приділяє навчанню письма та читання дітей дошкільного віку початкової школи, вивченню іноземних мов 
(особливо англійської мови), освоєнню матеріалу 3 деяких курсів історії та географії з використанням сервісів Веб 2.0. Проводить міжнародну проектну діяльність, створюючи он-лайн спільноти [9].

Таким чином можна зазначити, що тенденція створення віртуальних освітніх спільнот спостерігається у діяльності найбільш відомих освітніх мереж розглянутих вище. Особливе місце у віртуальному глобальному просторі займають освітні мережі, які з самого початку свого існування спрямовані на створення освітніх он-лайн спільнот поступово формуючи єдиний освітній простір у глобальному вимірі, наприклад:

- Мережа вчителів (Teachers network - Великобританія), яка охоплює початкову, середню та вищу школу і спрямована на інтегрування IКТ у процес викладання різних дисциплін (Мистецтво та дизайн; Громадянська освіта, Технології та дизайн, Англійська мова, Географія, Історія, ІКТ, Математика, Сучасні іноземні мови, Музика, Фізичне виховання, Релігійна освіта, Суспільствознавчі науки, Філософія). Таким чином створюються постійно діючі віртуальні спільноти вчителів-предметників [10].

- Мережа вчителів (Teachers network - США) охоплює всі рівні освіти починаючи $з$ початкової (середню та вищу), цільові групи - вчителі та учні, які створюють свої навчальні он-лайн середовища 3 метою підвищення якості навчання та інтегрування IКТ у навчальний процес [11].

- Мережа творчих вчителів (Росія) створена для педагогів, які зацікавлені у можливостях підвищення якості навчання за допомогою використання IКТ [12], надає різноманітні матеріали та ресурси, які стосуються використання IКТ у навчальному процесі, а також можливості спілкування 3 колегами.

Важливим аспектом $є$ створення віртуальних спільнот вчителівпредметників: ІКТ в початковій школі, Спільнота творчих вчителів інформатики, IКТ на уроках російської мови та літератури, Спільнота вчителів математики, Хімоз, Інтернет спільнота вчителів історії та суспільствознавства, Спільнота вчителів географії, Спільнота вчителів фізики, Економіка в школі, Спільнота вчителів біології та екології, Уроки творчості: мистецтво і технологій у школі, Спільнота педагогів з музики, Спільнота вчителів англійської мови, Спільнота 
вчителів німецької мови, Спільнота вчителів французької мови, Спільнота вчителів безпеки життєдіяльності, Спільнота вчителів фізичної культури краєзнавства.

- «Открытый класс. Сетевые образовательные сообщества» (Росія) [13] сприяє створенню віртуальних освітніх спільнот вчителів-предметників.

- Мережа Партнерство в навчанні [14] започаткована «Майкрософт Україна» у співробітництві з Академією педагогічних наук України, яка є першим українським професійним освітнім он-лайн ресурсом та Інтернет-спільнотою для педагогів, надає більш можливостей освітянам дізнатися про інноваційні IКТ 3 метою покращення якості навчання, а також:

- створювати професійні віртуальні спільноти;

- обмінюватися досвідом та ідеями;

- спільно працювати над розробкою уроків, навчальних і методичних; матеріалів та інше.

- Міжнародна освітня та ресурсна мережа „іEARN” (International Education and Resource Network) [15], на базі якої в Україні була створена національна мережа, діюча в багатьох українських школах. Основна спрямованість мережі - розвиток та застосування телекомунікацій в освіті. Методом роботи мережі $\epsilon$ метод проектів. Завдяки цьому i в процесі проведення телекомунікаційних проектів з біології, географії, фізики, інформатики, англійської мови, математики, літератури, української мови, образотворчого мистецтва, історії, екології та інших навчальних предметів створюються віртуальні освітні спільноти, об’єднаних спільною темою, ідеєю. Останнім часом спостерігається широке використання дослідницьких методів в проектній діяльності, що є результатом співпраці вчителів з програмою “ntel @ Навчання для майбутнього”.

\section{Висновки}

Таким чином, можна зробити висновок, що розвиток та інтегрування IКТ у системах освіти зарубіжних країн і України є одним із пріоритетних напрямів.

Глобальні освітні мережі такі як GINIE, GLORIAD, Global Knowledge Partnership (GKP), Xplora, Globalschoolnet, Educared, HappyChild, Teachers Network та інші відіграють у цих процесах важливу роль. Різноманітні можливості он-лайн 
ресурсів таких мереж (інтерактивні уроки, відео конференції та семінари, навчальні та інформаційні матеріали тощо) підвищують рівень та якість навчання.

Тенденцією розвитку глобальних освітніх мереж є створення віртуальних освітніх спільнот, що сприяє формуванню єдиного освітнього простору у глобальному вимірі.

Розвиток сучасних освітніх мереж та їх ресурсів потребує подальшого вивчення з метою використання позитивного досвіду їх діяльності освітянами та науковцями України.

\section{Список використаних джерел}

1. Розпорядженням Кабінету Міністрів України № 1722-р, Концепція Державної цільової програми впровадження у навчально-виховний процес загальноосвітніх закладів інформаційно-комунікаційних технологій "Сто відсотків" на період до 2015 року. - Сайт Міністерства освіти і науки України. [Електронний ресурс] . - Режим доступу: http://www.mon.gov.ua/

2. GINIE (Global Information Networks in Education) -Глобальні інформаційні мережі в освіті). - [Електронний ресурс]. - Режим доступу: http://portal.unesco.org/education/en/ . - Заголовок з екрану.

3. Глобальне партнерстов в ім'я знання GKP (Global Knowledge Partnership). [Електронний ресурс]. - Режим доступу: http://www.globalknowledge.org/. Заголовок з екрану.

4. Глобальна мережа GLORIAD. - [Електронний ресурс]. - Режим доступу: http://www.gloriad.org/gloriad/index.html. - Заголовок з екрану

5. Глобальна освітня мережа Xplora. - [Електронний ресурс]. - Режим доступу: http://www.xplora.org/ww/en/pub/xplora/. - Заголовок з екрану.

6. Global Development learning Network (Глобальна мережа 3 розвитку навчання) . - [Електронний ресурс]. - Режим доступу: http://web.worldbank.org/ . - Заголовок з екрану

7. Глобальна шкільна мережа Global School Network. - [Електронний pecypc]. Режим доступу: http://www.globalschoolnet.org/index.html. - Заголовок з екрану.

8. Іспанська освітня мережа EducaRed. - [Електронний ресурс]. - Режим доступу: http://www.educared.net/. - Заголовок з екрану 
9. Глобальна освітня мережа HappyChild. - [Електронний ресурс]. - Режим доступу: http://www.happychild.org/. - Заголовок з екрану.

10. Мережа вчителів (Teachers network - Великобританія) . - [Електронний pecypc]. - Режим доступу: http://www.theteachernet.co.uk/. - Заголовок з екрану 11. Мережа вчителів (Teachers network - США). - [Електронний ресурс]. Режим доступу: http://teachersnetwork.org/funders/. - Заголовок $з$ екрану

12. Сеть творческих учителей (Росія). - [Електронний ресурс]. - Режим доступу: http://www.it-n.ru/ . - Заголовок з екрану

13. Открытый класс. Сетевые образовательные сообщества. - [Електронний pecypc]. - Режим доступу: http://www.openclass.ru/ - Заголовок з екрану.

14. Мережа Партнерство в навчанні. - [Електронний ресурс]. - Режим доступу: http://ua.partnersinlearningnetwork.com/Pages/default.aspx. - Заголовок з екрану 15. Міжнародна освітня та ресурсна мережа «IEARN». - [Електронний ресурс]. - Режим доступу:http://www.iearn.org.ua/index.html. - Заголовок з екрану.

\title{
ГЛОБАЛЬНЫЕ ОБРАЗОВАТЕЛЬНЫЕ СЕТИ И ИХ КОММУНИКАТИВНЫЙ ПОТЕНЦИАЛ (ЗАРУБЕЖНЫЙ ОПЫТ)
}

\begin{abstract}
Малицкая Ирина Дмитриевна, старший научный сотрудник Информационно-аналитического отдела педагогических инноваций Института информационных технологий и средств обучения НАПН Украины, г. Киев, e-mail: Irina_Malitskaya@mail.ru
\end{abstract}

\section{Аннотация}

В статье проанализированы основные тенденции развития глобальных образовательных сетей, таких как: GINIE, GLORIAD, Global Knowledge Partnership (GKP), Хplora, которые направлены на создание виртуальных образовательных сообществ с последующим формированием единого образовательного пространства. Рассмотрены такие сети как: Globalschoolnet, Educared, HappyChild, Teachers Network, на основе которых создаются и успешно работают образовательные виртуальные сообщества. Определены основные формы учебных ресурсов образовательных сетей, которые используются в учебно-воспитательном процессе общеобразовательной школы зарубежных стран. 
Ключевые слова: информационно-коммуникационные технологии, глобальные образовательные сети, виртуальные образовательные сообщества, единое образовательное пространство.

\section{GLOBAL EDUCATIONAL NETWORKS AND THEIR COMMUNICATIVE POTENTIAL (FOREIGN EXPERIENCE)}

Irina D. Malitskaya, senior researcher of the Information-analytical department of pedagogical innovations of the Institute of Information Technologies and Learning Tools of the National Academy of Pedagogical Sciences of Ukraine, Kyiv, e-mail: Irina_malitskaya@mail.ru

\section{Resume}

In the article the main tendencies of global educational nets development such as: GINIE, GLORIAD, Global Knowledge Partnership (GKP), Xplora are analized; it is determined their approaching to the creation of virtual educational communities which leads to formation of common education space. There are considered such nets as: Globalschoolnet, Educared, HappyChild, Teachers Network, which are the base for creation and successful work for educational virtual communities. The main forms of educational nets resources using in secondary school educational process of foreign countries are determined.

Keywords: information and communication technologies, global educational networks, virtual educational communities, common education space.

Матеріал надійшов до редакції 16.05.2011 р. 